\title{
First record of the behavior of latex drainage by Trigona spinipes (Fabricius) (Hymenoptera, Apidae) in laticiferous flowers
}

\author{
Cristiana Koschnitzke ${ }^{1}$ \\ ${ }^{1}$ Departamento de Botânica, Museu Nacional, Universidade Federal do Rio de Janeiro, Quinta da Boa Vista s/n, São Cristóvão, 20590-040 Rio de \\ Janeiro-RJ, Brasil. criskosch@yahoo.com.br
}

\begin{abstract}
First record of the behavior of latex drainage by Trigona spinipes (Fabricius) (Hymenoptera, Apidae) in laticiferous flowers. This paper describes the behavior of the bee Trigona spinipes, to avoid the latex, when piercing the base of the tubular corolla of the flowers of Mandevilla guanabarica in order to steal the nectar.
\end{abstract}

KEYWORDS. Apocynaceae; floral drilling; stingless bee.

RESUMO. Primeiro registro do comportamento de drenagem de latex de Trigona spinipes (Fabricius) (Hymenoptera, Apidae) em flores latescentes. Este trabalho descreve o comportamento da abelha Trigona spinipes para evitar o látex quando perfura a base da corola tubular das flores de Mandevilla guanabarica ao roubar néctar.

PALAVRAS-CHAVE. Abelha sem ferrão; Apocynaceae; perfuração floral.

Bees of the genus Trigona Jurine are frequent nectar robbers in flowers with difficult-to-reach nectar from several families of plants, including the Bignoniaceae, Caprifoliaceae, Fabaceae, Malvaceae, and Verbenaceae (Barrows 1976, 1980; Barros 2001; Correia et al. 2005).

Mandevilla guanabarica Casaretto ex M.F. Sales, Kinoshita-Gouveia \& A. Simões is a laticiferous climbing vine, with showy yellow flowers with an infundibuliform corolla and a cylindrical tube (Sales et al. 2006).

In a study on the floral biology of M. guanabarica (C. Koschnitzke unpublished data), it was observed that Trigona spinipes (Fabricius, 1793) pierces the base of the corolla tube to reach the nectar. The question then arose as to whether this bee can handle the abundant latex in the floral tissues during drilling. The present study describes the behavior of T. spinipes in drilling the flowers of M. guanabarica.

The study was carried out in the Environmental Protec-

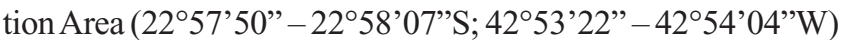
in the Municipality of Maricá, State of Rio de Janeiro, Brazil. Field observations were made from January 2004 to September 2005. The nectar-robbing behavior was recorded and analyzed during 56 hours of field observations. The observation intervals were from 6:00 to 12:00 a.m., or from 12:00 a.m. to 5:00 p.m.

Trigona spinipes generally lands on the outside of the corolla tube at 7:15-9:00 a.m., after the main pollinators have already made their first visits (6:00-7:00 a.m.). Up to four individuals of $T$. spinipes may land at the same time on the flower, but, in general, only two individuals can work together in the same hole and, in most cases, only one bee makes the hole. The bee first makes several small bites in the corolla tube next to the point that will be pierced. From these small bites, a small amount of latex flows out, and coagulates upon exposure to air. The bees then begin to scrape the tissue with their mandibles, making the region translucent, until the hole begins to appear. At this stage, there is no visible latex emission from the tissue. The bees remove tissue from the corolla forming small balls, rolling them with their mandibles and pulling them with the proboscis to the most apical part of the corolla, where they release it, and then return to the hole being made. When the hole is complete, these small balls are glued on the outside of the corolla tube. Next, small pieces of corolla tube are gradually removed from the borders, increasing the open area. Then, the bees begin to attempt to insert their heads into the corolla tube through the hole. When the hole is finally large enough for a bee to place its entire head inside the corolla tube to take nectar, it generally does not remain in the flower afterwards. The bees constantly return to the flower, using the same hole. This entire process takes about 50 minutes. In subsequent visits, the bees continue cutting more pieces, and the edges of the hole become more rounded. During an intense robbing event, they may make two holes in the same flower, and in addition to the corolla, the style and the ovary also can become damaged.

The latex can occur in the plant epidermis in a dense network of very thin laticifers (Lewinsohn \& Vasconcellos-Neto 2000). The presence of latex may be a defense against nectar robbing (Inouye 1983). However, the latex was not an obstacle 
to perforation of the corolla tube by $T$. spinipes. For other species of Trigona, as T. williana Friese, 1900 and T. recursa Smith, 1863 was observed collecting latex from the bark of Mammea americana (L.) Jacq. (Clusiaceae) showing that the latex can also be a resource for those bees (Pereira $\&$ Tannús-Neto 2009).

However, the latex of $M$. guanabarica was not used by bees because the nectar in the tube was the desired resource. So the several initial bites by $T$. spinipes adjacent to the area to be drilled, serve to drain and block the latex flow to the area.

The behavior of bleeding latex was mainly observed in some beetles and larvae of Lepidoptera, especially hawkmoths, which use their mandibles to pierce the petiole or veins in leaves to lance the laticifers, thus draining the latex from the portions of the leaves where they will feed (Dussourd \& Eisner 1987; Lewinsohn \& Vasconcellos-Neto 2000).

There are no reports about the behavior of stingless bees to pierce the corolla tube of laticiferous flowers to remove the nectar. This is the first record of the draining the latex by Trigona spinipes in laticiferous flowers.

\section{ACKNOWLEDGMENTS}

Thanks to the students Mara da Silva Rodrigues (scientific initiation scholarship from FAPERJ) and Pablo R. Marques for field assistance and to Janet Reid for reviewing the manuscript and for the correction of the English text.

\section{REFERENCES}

Barros, M. G. 2001. Pollination ecology of Tabebuia aurea (Manso) Benth. \& Hook. and T. ochracea (Cham.) Standl. (Bignoniaceae) in Central Brazil cerrado vegetation. Revista Brasileira de Botânica 24: 255261.

Barrows, E. M. 1976. Nectar robbing and pollination of Lantana camara (Verbenaceae). Biotropica 8: 132-135.

Barrows, E. M. 1980. Robbing of exotic plants by introduced carpenter and honey bees in Hawaii, with comparative notes. Biotropica 12: $23-$ 29.

Correia, M. C. R.; M. C. B. Pinheiro \& H. A. Lima. 2005. Biologia floral e polinização de Arrabidaea conjugate (Vell.) Mart. (Bignoniaceae). Acta Botanica Brasilica 19: 501-510.

Dussourd, D. E. \& T. Eisner. 1987. Vein-cutting behavior: insect counterplay to the latex defense of plants. Science 237: 898-901.

Inouye, D. W. 1983. The ecology of nectar robbing, p. 153-173. In: B. Bentley \& T. Elias (eds). The biology of nectaries. New York, Columbia University Press, 259 p.

Lewinsohn, T. M. \& J. Vasconcellos-Neto. 2000. Como insetos sabotam defesas de plantas: o caso do látex., p. 281-298. In: R. P. Martins; T. M. Lewinsohn \& M. S. Barbeitos (eds.). Ecologia e comportamento de insetos. Série Oecologia Brasiliensis, vol. VIII. Rio de Janeiro, Universidade Federal do Rio de Janeiro, 435 p.

Pereira, C. D. \& J. Tánnus-Neto. 2009. Observações sobre abelhas sem ferrão (Hymenoptera: Meliponini) coletoras de látex em Abricó do Pará Mammea americana (L.) Jacq. (Clusiceae), Manaus, State of Amazonas, Brazil. Bioscience Journal 5: 133-135.

Sales, M. F.; L. S. Kinoshita \& A. O. Simões. 2006. Eight new species of Mandevilla subgenus Mandevilla (Apocynaceae, Apocynoideae) from Brazil. Novon 16: 113-129. 